Supplementary Information

\title{
Redox-driven Reversible Structural Evolution of Isolated Silver Atoms Anchored on Specific Sites on $\mathrm{Y}-\mathrm{Al}_{2} \mathrm{O}_{3}$
}

Hiroe Kubota, ${ }^{\dagger}$ Shinya Mine,${ }^{\dagger}$ Takashi Toyao, $^{\dagger, \ddagger}$ Zen Maeno, ${ }^{\dagger}$ Ken-ichi Shimizu${ }^{* \dagger, \ddagger}$

${ }^{\dagger}$ Institute for Catalysis, Hokkaido University, N-21, W-10, Sapporo 001-0021, Japan

‡Elements Strategy Initiative for Catalysts and Batteries, Kyoto University, Katsura, Kyoto 615-8520, Japan 

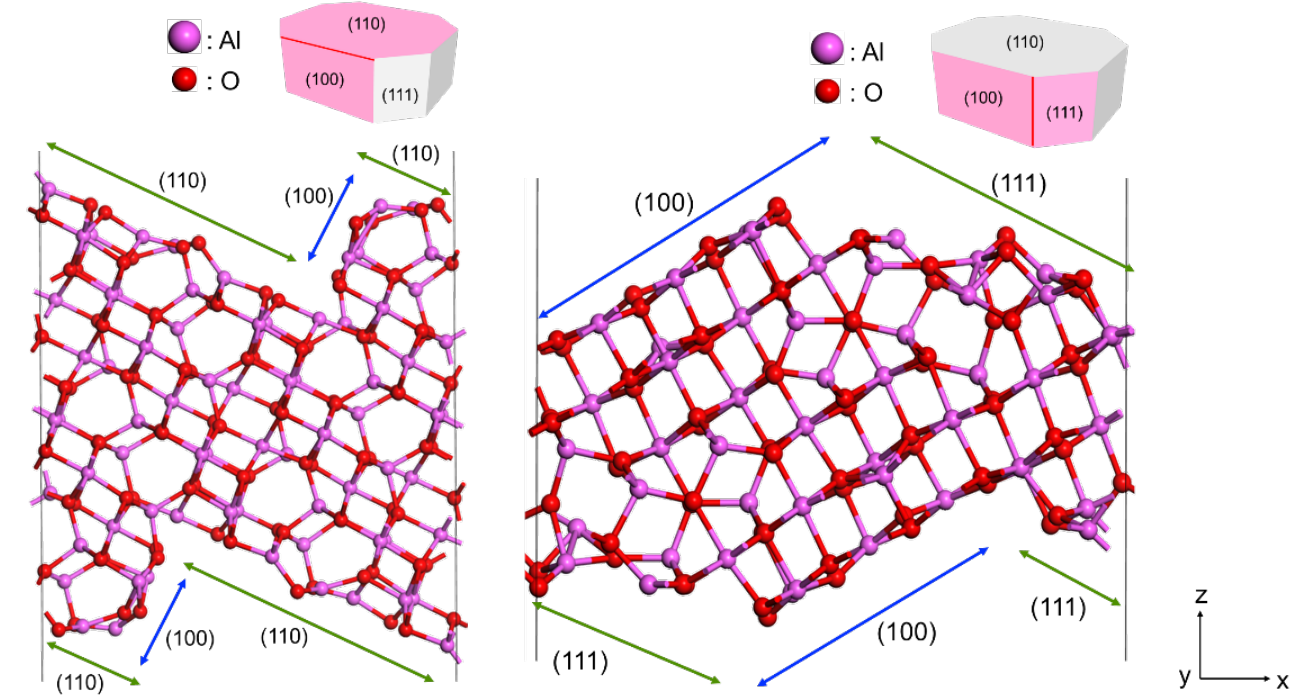

Figure $\mathrm{S} 1$. Side view of optimized periodic models of $\gamma-\mathrm{Al}_{2} \mathrm{O}_{3}$ surface. (a) $\gamma-\mathrm{Al}_{2} \mathrm{O}_{3}(110)-(100)$ surface, (b) $\gamma-\mathrm{Al}_{2} \mathrm{O}_{3}(100)-(111)$ surface. (pink: $\mathrm{Al}$ atom, red: $\mathrm{O}$ atom)

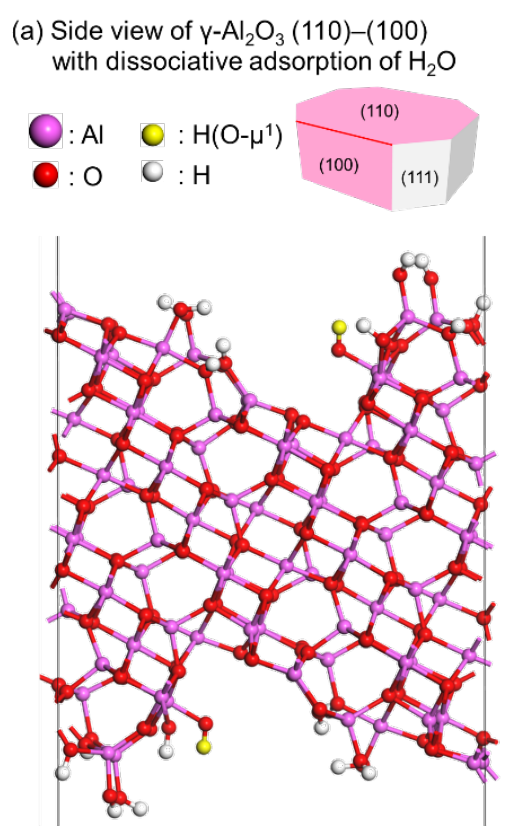

$\mathrm{OH}$ coverage $=3.5 \mathrm{OH} / \mathrm{nm}^{2}$
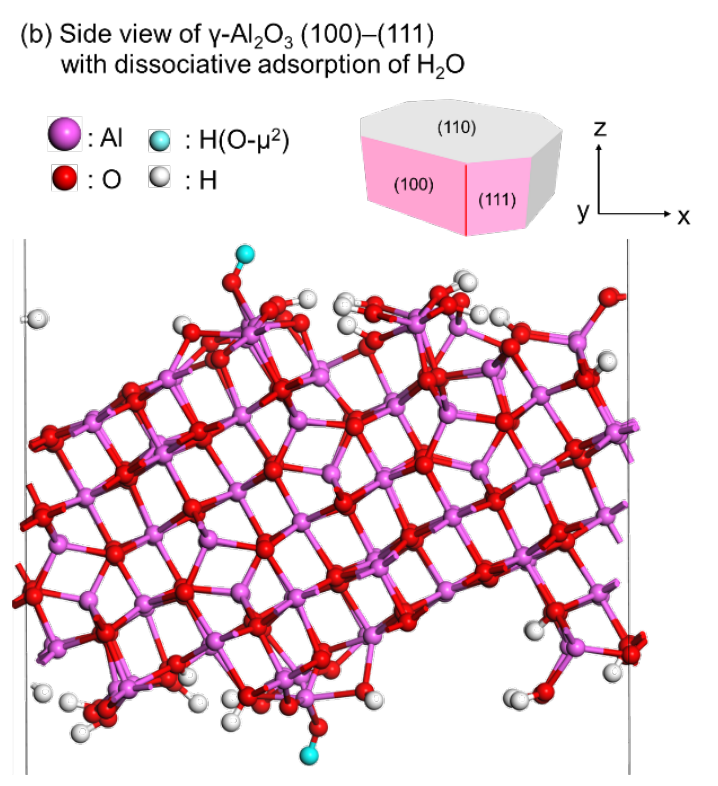

$\mathrm{OH}$ coverage $=3.4 \mathrm{OH} / \mathrm{nm}^{2}$

Figure S2. Side view of the optimized periodic model of a $y-\mathrm{Al}_{2} \mathrm{O}_{3}$ surface with dissociative adsorbed $\mathrm{H}_{2} \mathrm{O}$. (a) $\gamma-\mathrm{Al}_{2} \mathrm{O}_{3}(110)-(100)$ surface, (b) $\gamma-\mathrm{Al}_{2} \mathrm{O}_{3}(100)-(111)$ surface. (pink: Al atom, cyan: Ag atom, red: $\mathrm{O}$ atom, white: $\mathrm{H}$ atom, blue: $\mathrm{H}$ atom in terminal hydroxyls on $\gamma-\mathrm{Al}_{2} \mathrm{O}_{3}(100)$ surface, and yellow: $\mathrm{H}$ atom in doubly bridging hydroxyls on $\mathrm{y}-\mathrm{Al}_{2} \mathrm{O}_{3}$ (100) surface.) 


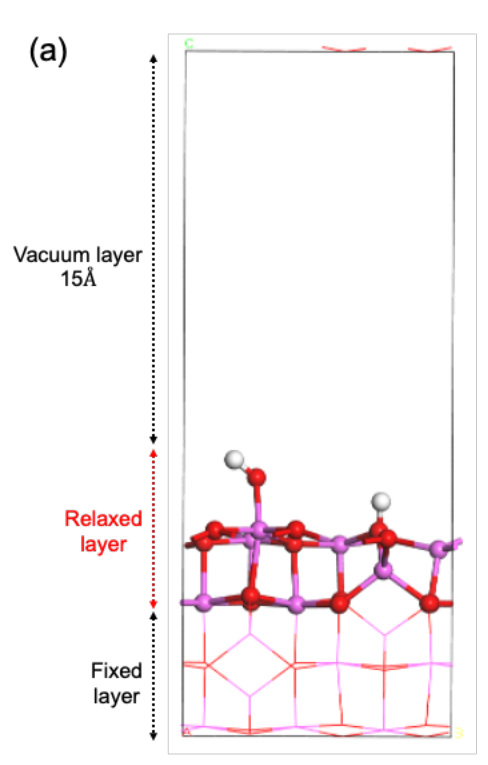

(c)

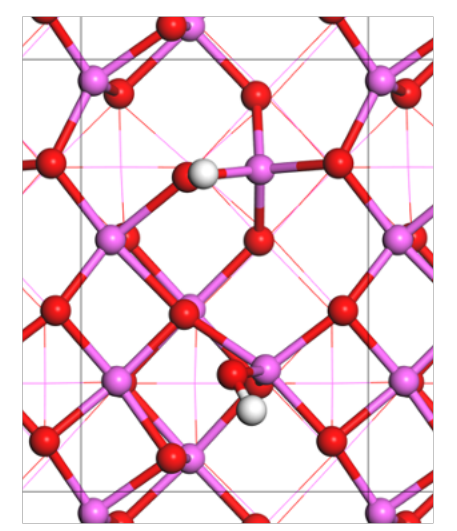

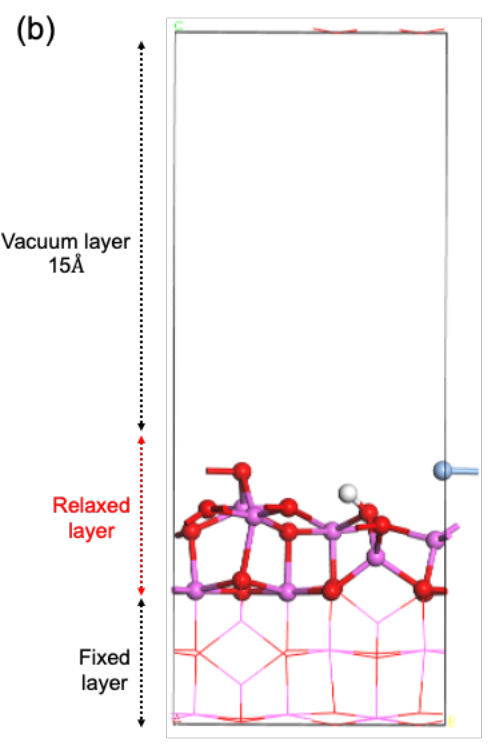

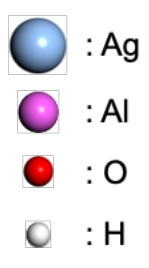

(d)

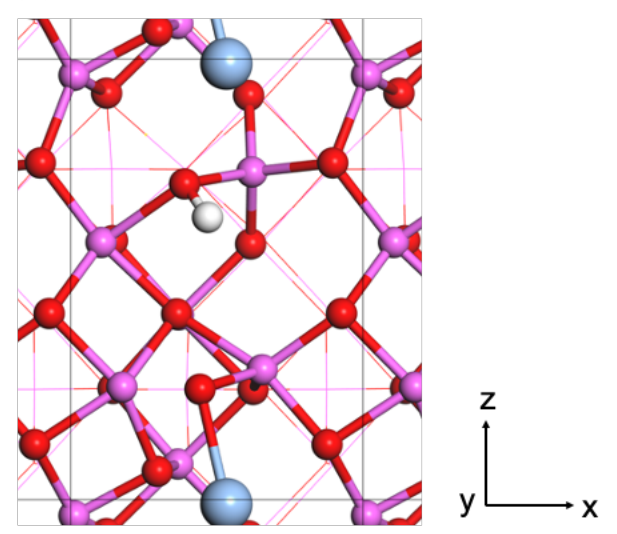

Figure S3. Optimized periodic models of $y-\mathrm{Al}_{2} \mathrm{O}_{3}$ surface. Side and top view of (a), (c) $\gamma-\mathrm{Al}_{2} \mathrm{O}_{3}$ (100) surface and (b), (d) $\mathrm{Ag} / \mathrm{y}-\mathrm{Al}_{2} \mathrm{O}_{3}$ (100) surface. Relaxed layers are represented by balls and sticks, and fixed layers are represented by lines. (pink: Al atom, cyan: Ag atom, red: $\mathrm{O}$ atom, and white: $\mathrm{H}$ atom.)

Table S1. Compositional formula and lattice parameters of the $\gamma-\mathrm{Al}_{2} \mathrm{O}_{3}$ step-edge models.

\begin{tabular}{llllllll}
\hline Step-edge model & Composition formula & $\mathrm{a}(\AA)$ & $\mathrm{b}(\AA)$ & $\mathrm{c}(\AA)$ & $\alpha\left(^{\circ}\right)$ & $\beta\left(^{\circ}\right)$ & $\gamma\left({ }^{\circ}\right)$ \\
\hline$\gamma-\mathrm{Al}_{2} \mathrm{O}_{3}(110)-(100)$ & $\left(\mathrm{H}_{2} \mathrm{O}\right)_{10} / \mathrm{Al}_{96} \mathrm{O}_{144}$ & 17.02 & 8.41 & 37.35 & 90.00 & 97.02 & 90.00 \\
$\gamma-\mathrm{Al}_{2} \mathrm{O}_{3}(100)-(111)$ & $\left(\mathrm{H}_{2} \mathrm{O}\right)_{14} / \mathrm{Al}_{96} \mathrm{O}_{144}$ & 18.66 & 11.17 & 36.40 & 89.48 & 88.08 & 90.26 \\
\hline
\end{tabular}


(a)

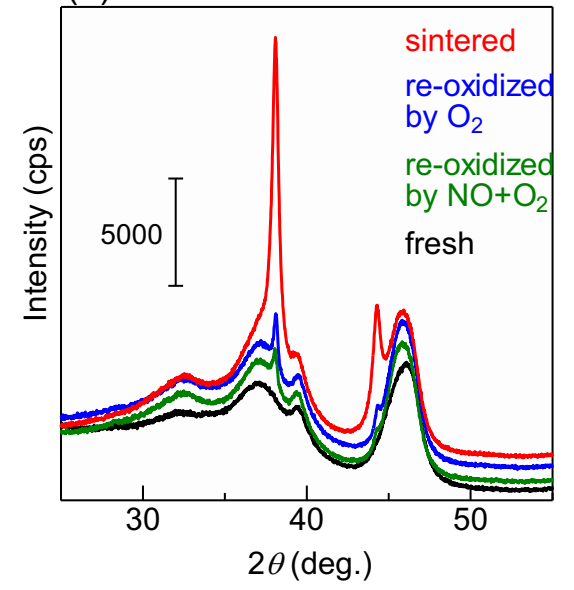

(b)

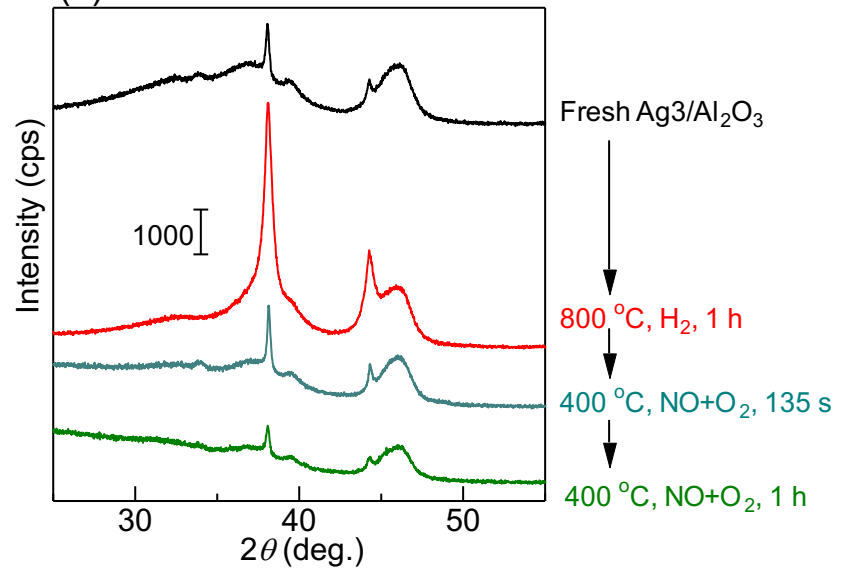

Figure S4. Full range of XRD patterns for (a) Figure 1a and (b) Figure 4(i).

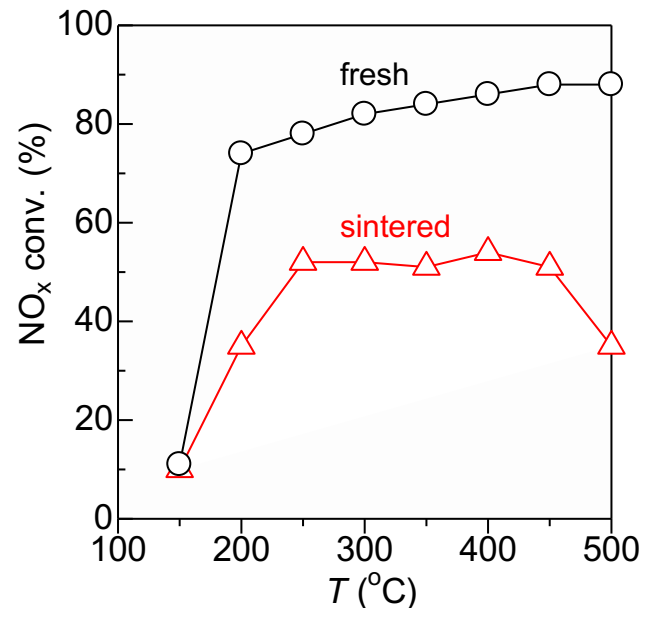

Figure S5. $\mathrm{H}_{2}-\mathrm{NH}_{3}-\mathrm{SCR}$ by fresh sintered $\mathrm{Ag}_{3} / \mathrm{Al}_{2} \mathrm{O}_{3}(15 \mathrm{mg})$ under low $\mathrm{H}_{2}$ concentration conditions: 500 ppm NO, 500 ppm NH3, 0.2\% $\mathrm{H}_{2}, 10 \% \mathrm{O}_{2}$. 
(a)

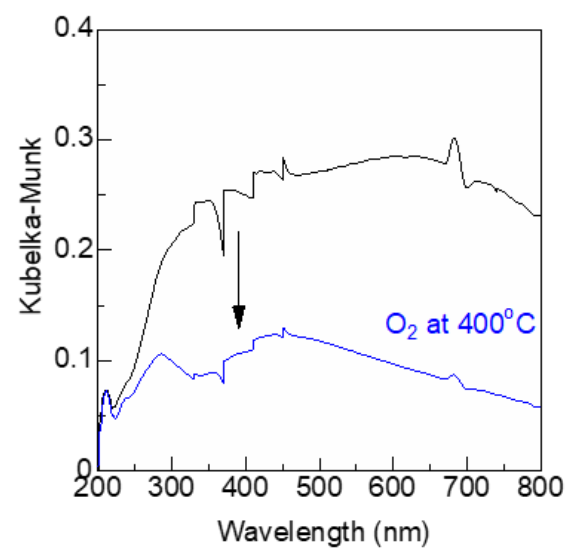

(b)

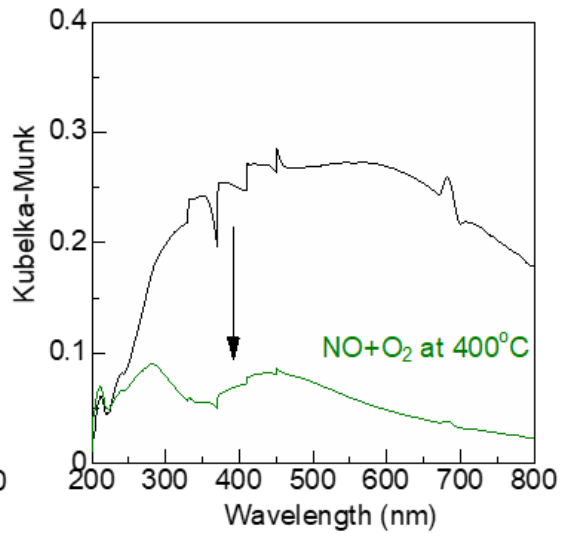

(c)

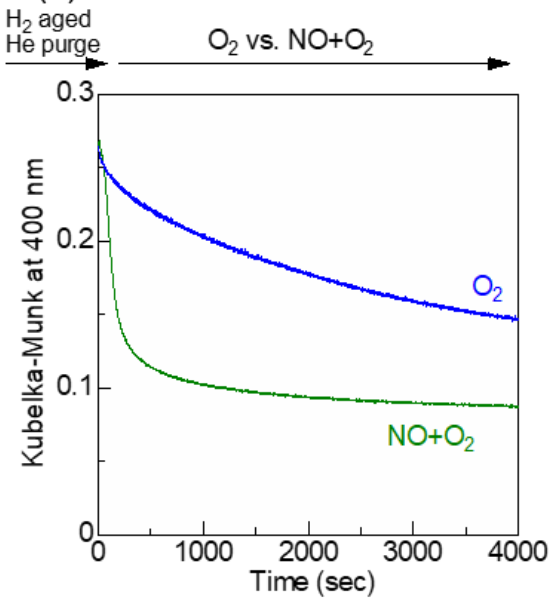

Figure S6. In situ UV-vis spectra of $\mathrm{Ag}_{3} / \mathrm{Al}_{2} \mathrm{O}_{3}$ after reduction by $\mathrm{H}_{2}$ at $800{ }^{\circ} \mathrm{C}$ (black lines) and subsequent re-oxidation at $400{ }^{\circ} \mathrm{C}\left(4000 \mathrm{~s}\right.$ ) by (a) $10 \% \mathrm{O}_{2}$ and (b) $500 \mathrm{ppm} \mathrm{NO}+10 \% \mathrm{O}_{2}$. (c) Time dependence of the UV-vis signal intensity due to Ag NPs during re-oxidation.

(a)

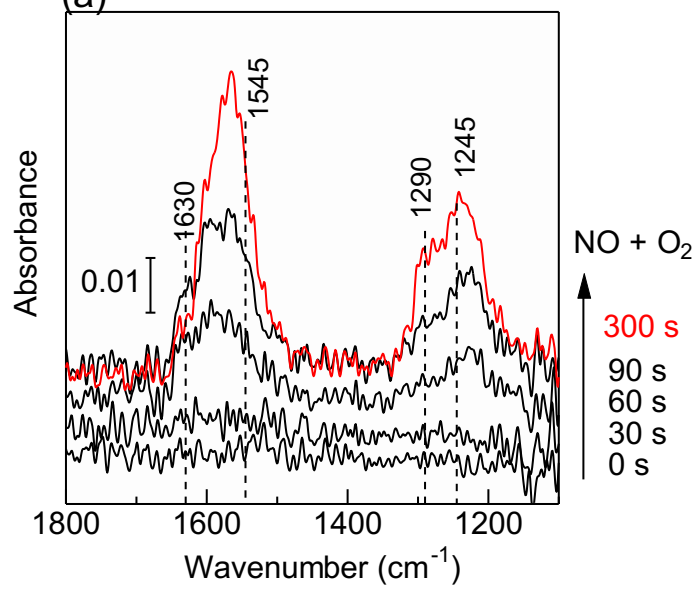

(b)

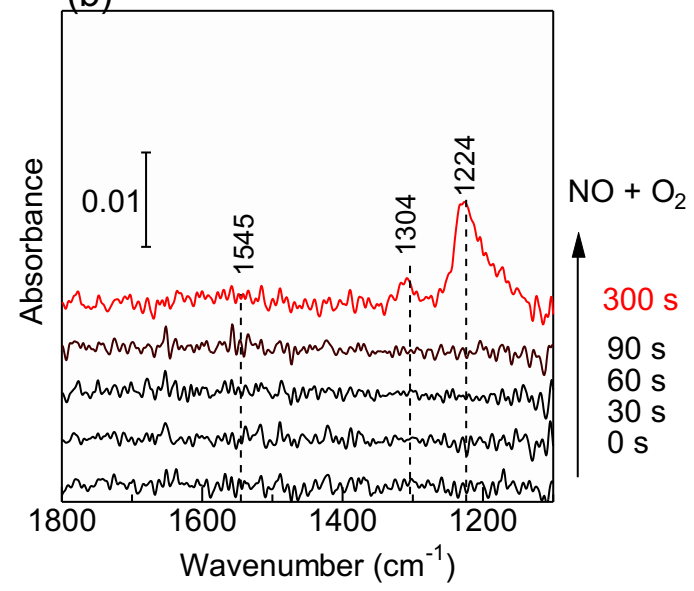

Figure S7 Time-resolved in situ IR spectra of the adsorbed species on (a) $\gamma-\mathrm{Al}_{2} \mathrm{O}_{3}$ and (b) fresh $\mathrm{Ag} 3 / \mathrm{Al}_{2} \mathrm{O}_{3}$ under the $\mathrm{NO}+\mathrm{O}_{2}$ atmosphere at $400{ }^{\circ} \mathrm{C}$. 


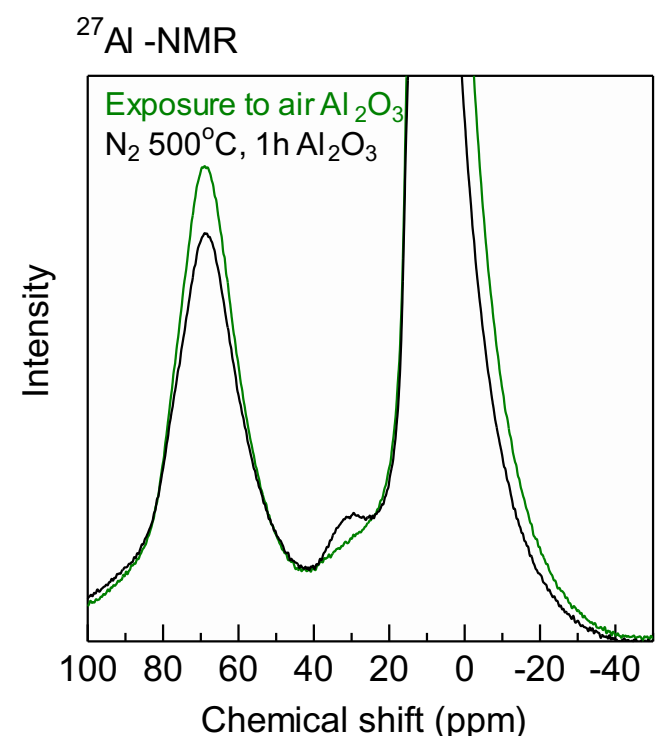

Figure S8. Normalized ${ }^{27} \mathrm{Al} N \mathrm{NMR}$ spectra of $\mathrm{\gamma}-\mathrm{Al}_{2} \mathrm{O}_{3}$ dehydrated under $\mathrm{N}_{2}$ at $500{ }^{\circ} \mathrm{C}$ for $1 \mathrm{~h}$ (black), followed by rehydration under ambient conditions for $1 \mathrm{~h}$ (green).

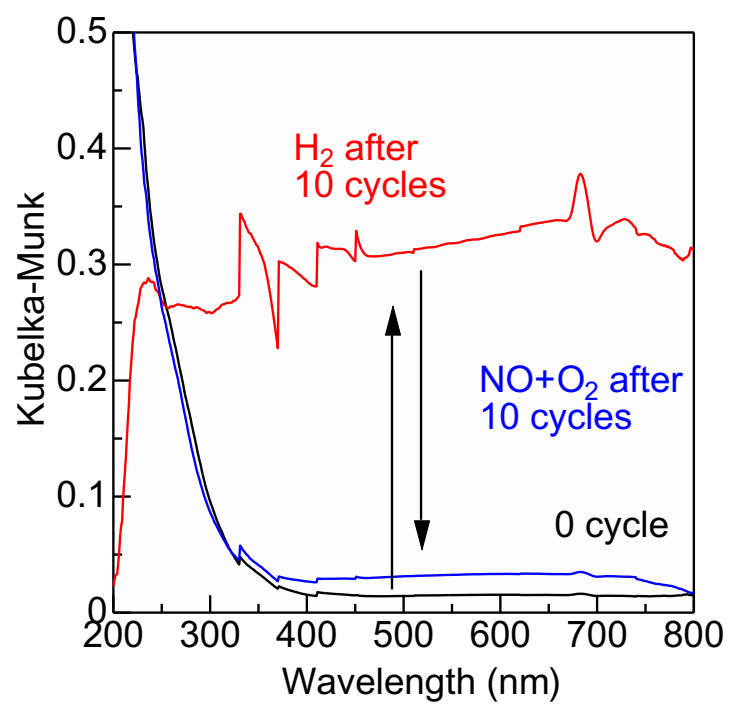

Figure S9. In situ UV-vis spectra $\left(600{ }^{\circ} \mathrm{C}\right.$ ) of fresh $\mathrm{Ag}_{3} / \mathrm{Al}_{2} \mathrm{O}_{3}$ (black; in $\mathrm{He}$ ), after 10 cycles under $\mathrm{H}_{2}$ (red), and subsequent exposure to $\mathrm{NO}+\mathrm{O}_{2}$ (blue). 


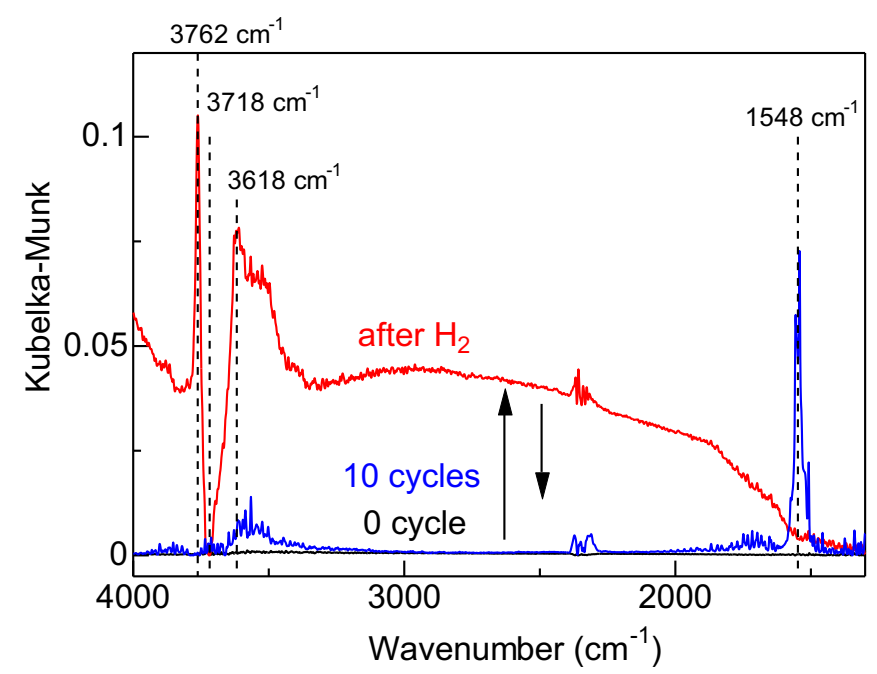

Figure S10. In situ DRIFT spectra $\left(600{ }^{\circ} \mathrm{C}\right.$ ) of fresh $\mathrm{Ag} / \mathrm{Al}_{2} \mathrm{O}_{3}$ (black; in $\left.\mathrm{He}\right)$, after 10 cycles under $\mathrm{H}_{2}$ (red), and subsequent exposure to $\mathrm{NO}+\mathrm{O}_{2}$ (blue).

Table S2. Bader charge of Ag, $\mathrm{O}$, and $\mathrm{H}$.

\begin{tabular}{llll}
\hline Model & Bader charge & & \\
& $\mathrm{Ag}$ & $\mathrm{H}$ & $\mathrm{O}$ \\
\hline $\mathrm{Ag}_{2} \mathrm{O}$ & 0.41 & & -0.83 \\
$\gamma-\mathrm{Al}_{2} \mathrm{O}_{3}(110)$ & & 0.67 & -1.49 \\
$\mathrm{Ag}$ on $\gamma-\mathrm{Al}_{2} \mathrm{O}_{3}(110)$ & 0.44 & & -1.20 \\
\hline
\end{tabular}




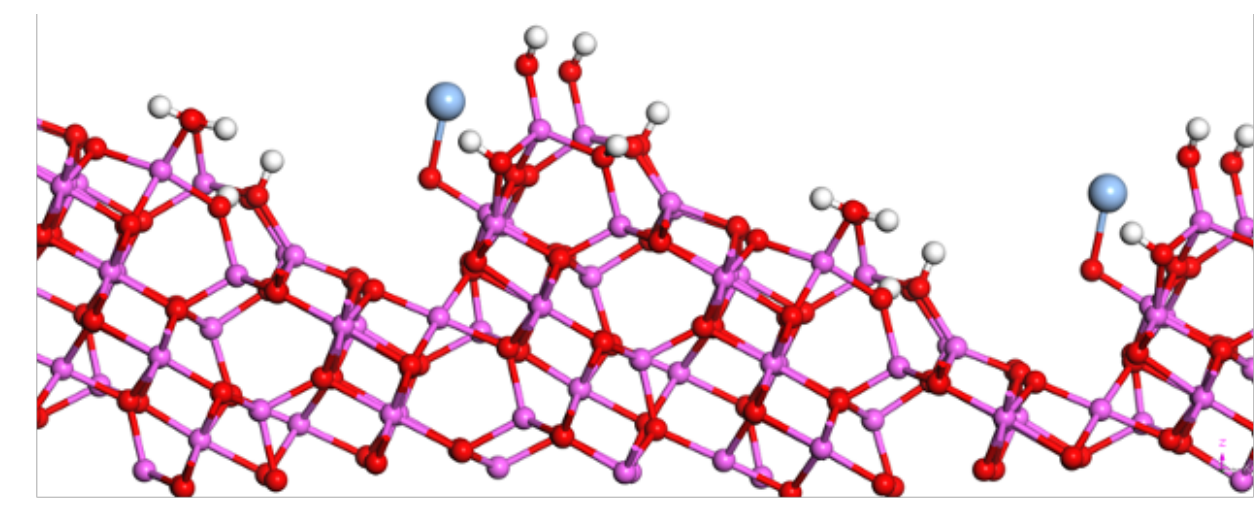

(110)
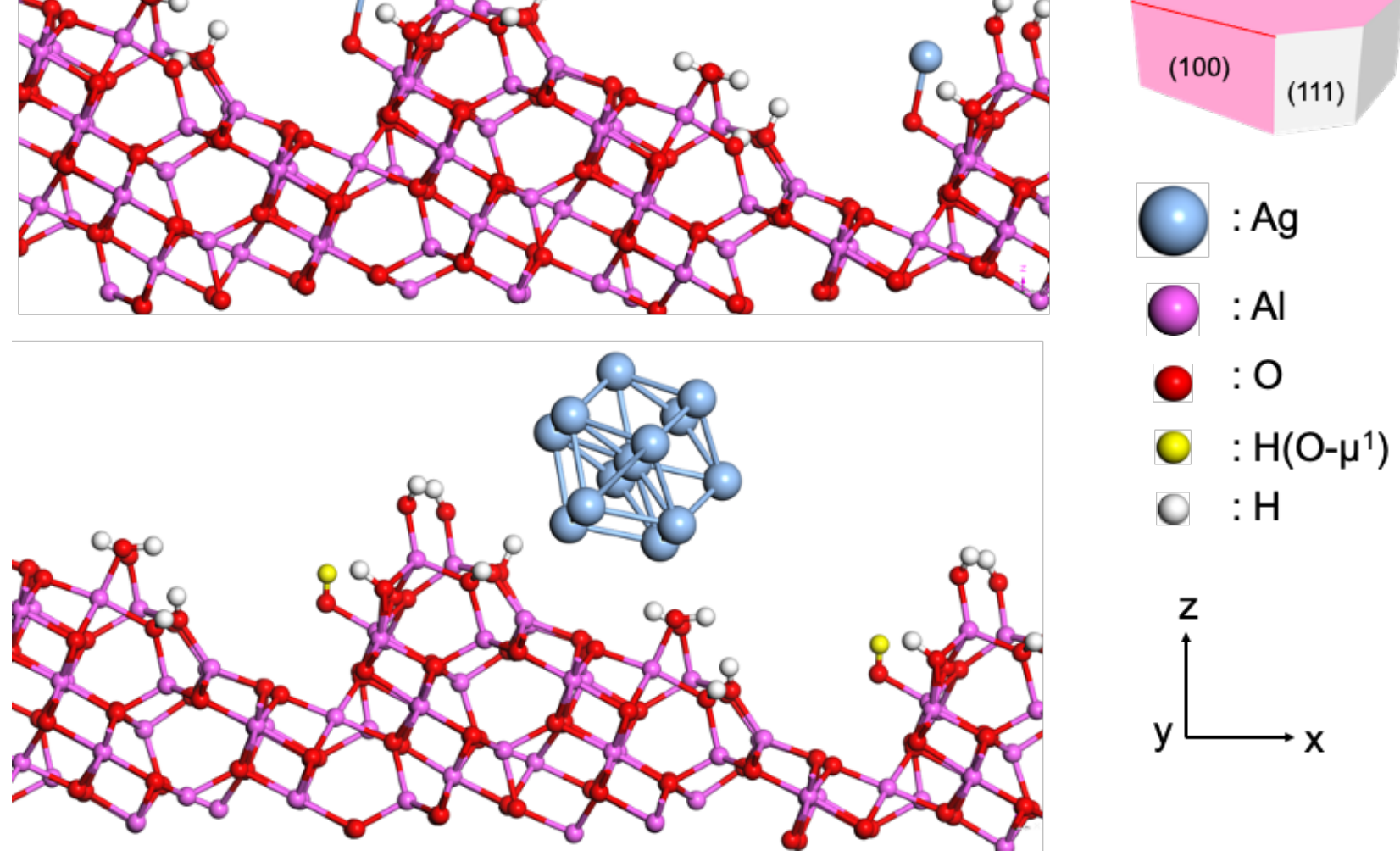

Figure S11. Surface structure models of (a) dispersed Ag species and (b) aggregated Ag species on a $\gamma-\mathrm{Al}_{2} \mathrm{O}_{3}$ (110)-(100) step-edge surface (cyan: Ag atom, pink: $\mathrm{Al}$ atom, red: $\mathrm{O}$ atom, yellow: $\mathrm{H}$ atom in terminal hydroxyls, and white: $\mathrm{H}$ atom). When $\mathrm{Ag}$ atoms aggregate, the $\mathrm{H}$ atoms of the terminal hydroxyl are regenerated. 